
УДК 615.456.1:615.375:617.3
DOI: $10.32352 / 0367-3057.5 .19 .08$
О. О. САЛІЙ ${ }^{1}$ (https://orcid.org/0000-0001-7103-2083), канд. фарм. наук, доцент,
О. В. ЛОСЬ ${ }^{2}$ (https://orcid.org/0000-0002-7830-6937),
О. П. БАУЛА ${ }^{1}$ (https://orcid.org/0000-0003-4305-6517), канд. хім. наук, доцент,
К. Ф. МАЦЮЦЯ ${ }^{1}$ (https://orcid.org/0000-0001-6704-6511)
${ }^{1}$ Киівський національний університет технологій та дизайну
${ }^{2}$ Фармацевтична корпорачія «Юрія-Фарм», м. Київ

\section{РОЗРОБЛЕННЯ СКЛАДУ ТА ТЕХНОЛОГІЇ ВИРОБНИЦТВА ІН'СКЦІЙНОГО ЛІКАРСЬКОГО ЗАСОБУ ДЛЯ ВНУТРШШНЬОСУГЛОБОВОГО ВВЕДЕННЯ НА ОСНОВІ ГІАЛУРОНАТУ НАТРІЮ}

Ключові слова: гіалуронат натрію; розчин для ін>єкцій; розробка складу; технологія виробництва; стабілізація розчину

O. O. SALIY ${ }^{1}$ (https://orcid.org/0000-0001-7103-2083),

O. V. LOS ${ }^{2}$ (https://orcid.org/0000-0002-7830-6937),

O. P. BAULA ${ }^{1}$ (https://orcid.org/0000-0003-4305-6517),

K. F. MATSIUTSIA ${ }^{1}$ (https://orcid.org/0000-0001-6704-6511)

${ }^{1}$ Kyiv National University of Technologies and Design

${ }^{2}$ Pharmaceutical Corporation «Yuria-Pharm», Kyiv

\title{
DEVELOPMENT OF THE COMPOSITION AND PRODUCTION TECHNOLOGY OF INJECTION MEDICATION FOR INTRA-ARTICULAR INTRODUCTION BASED ON SODIUN HYALURONATE
}

Key words: sodium hyaluronate; solution for injection; composition development; production technology; stabilization of the solution

Остеоартроз є найпоширенішим захворюванням опорно-рухового апарату людини, який у 10-30\% випадків призводить до непрацездатності різного ступеня, причому вік пацієнта є одним із найважливіших факторів ризику [1].

Класичні способи лікування дегенеративних запальних захворювань суглобів мають значні недоліки. Хірургічні операції зі заміни суглоба є найефективнішим рішенням, але такий метод дуже ризикований та дорогий, особливо для людей похилого віку. Консервативне лікування нестероїдними протизапальними препаратами має короткочасний ефект, значну побічну дію на кишково-шлунковий тракт та не покращує прогноз виліковування у довгостроковій перспективі. Пероральні та парентеральні хондропротектори на основі хондроітину проявляють дуже слабкий структурномодифікуючий ефект, на основі глюкозаміну справляють повільний терапевтичний ефект, максимум клінічної дії спостерігається після застосування препаратів упродовж 2-3 місяців [2]. Як альтернативу вищенаведеним методам розглядають природні полімери, такі як полісахариди, як носії для доставки лікарських засобів у суглобовий хрящ та синовіальну рідину завдяки їх біосумісності, біодеградації та широкого розповсюдження у природі [3]. Близько 15 років назад було розроблено препарати для внутрішньосуглобового (інтрасинавіалього) введення на основі гіалуронової кислоти, які наразі вважають одним із найбільш ефективних та безпечних методів лікування артрозів як колінних, так і тазостегнових суглобів $[4,5,6]$.

Асортимент лікарських засобів, що містять гіалуронову кислоту у формі натрієвої солі для введення в синовіальну порожнину на українському ринку представлено дуже обмежено, а саме препаратами Сингіал ${ }^{\circledR}$ p-н д/ін., 10 мг/мл, у шприцях по 2 мл, виробництва ПАТ Фармак сумісно з «Лайф Саенсіз Лтд», Корея, та Гіалган ${ }^{\circledR}$ p-н д/iн., 20 мг/2 мл у флаконах, виробництва Фідіа Фармацевтика С.п.А., Італія. Обмеження асортименту зумовлено тим, що біотехнологічні продукти мають свою специфіку, що представлено в підходах до фармацевтичної розробки, джерел постачання та по(C) Колектив авторів, 2019 
ходження активних речовин, доведення ефективності дії, порядку реєстрації та подальшим розміщенням на ринку [7].

3 економічної сторони фармацевтична промисловість має тенденцію до нестабільності, що пов'язано з економічною кризою та постійними змінами у задоволенні потреби ринку (нові захворювання, спалахи) та потреб клієнтів (якість, новизна) [8], що потребує впровадження новітніх технологій, відмінних від стандартних технологій лікарських засобів, до складу яких входять хімічні речовини. Таким чином, розроблення складу та пошук новітніх технологічних аспектів лікарських засобів біотехнологічного походження є актуальним напрямом сьогодення фармації.

Мета роботи - розроблення складу та технології виготовлення ін'єкційного розчину кислоти гіалуронової у формі натрію гіалуронату для терапії дегенеративних запальних захворювань суглобів.

\section{М а т е р і л и т а ме тоди дослідження}

Розроблення складу розчину для ін'єкцій здійснювали зі застосуванням зразків активного фармацевтичного інгредієнту (АФІ) кислоти гіалуронової у формі натрію гіалуронату виробництва «Attix Pharmaceuticals», Канада. За своїми фізико-хімічними характеристиками АФІ повністю відповідає вимогам Свропейської фармакопеї та являє собою білий або майже білий дуже гігроскопічний порошок або гранули, помірно розчинний у воді $\mathrm{P}$, практично не розчинний у $96 \%$ етанолі та ацетоні $\mathrm{P}$.

Під час розроблення складу лікарської форми як стабілізатор та пролонгатор застосовували допоміжну речовину 1,4-бутандіол-дигліцидиловий ефір (далі - БДДЕ). Оскільки молекули нестабілізованного натрію гіалуронату відносно швидко руйнуються гіалуронідазами людського організму, введення БДДЕ утворює «містки» між окремими молекулами гіалуронату натрію та підвищує таким чином стійкість діючої речовини до розкладання in vivo.

Оцінку результатів випробувань під час вибору оптимальної технології приготування розчину для ін'єкцій на основі натрію гіалуронату виконували візуальним методом (опис, прозорість) та методом ротаційної віскозиметрії (в'язкість) [9].

Придатність режиму стерилізації визначали фізико-хімічними методами (опис, прозорість, в'язкість, $\mathrm{pH}$ розчину) і мікробіологічним методом (стерильність) згідно 3 вимогами ДФУ.

Кількісний вміст натрію гіалуронату визначали методом спектрофотометрії (ДФУ, 2.2.25) із використанням реагенту карбазолу [10].

\section{Результати дослідження та обговорення}

У зв'язку з тим, що молекули гіалуронату натрію відносно швидко руйнуються гіалуронідазами людського організму, тривалість дії лікарського засобу відносно коротка, декілька місяців [11], та постійно потребує повторних ін'єкцій. Таким чином, для стабільності ін'єкційного розчину та пролонгації терапевтичного ефекту необхідно використовувати гіалуронат натрію з максимально можливою молекулярною масою, приблизно 1,5-2,5 Мда, та застосовувати стабілізатор для запобігання деструкції молекули діючої речовини.

Функціональне призначення стабілізатора - за допомогою ковалентних зв'язків утворювати поперечні зшивки лінійних молекул натрію гіалуронату і такими чином формувати стійку макромолекулярну мережу гіалуронату натрію [12]. Отримані таким чином поперечно-зшиті молекули гіалуронату натрію стабільні, не розщеплюються ферментами людського організму у порожнині суглоба та проявляють пролонговану дію. У результаті технологічної операції оброблення стабілізатором між молекулами біополімеру виникає щільне зчеплення, що дає змогу діючій речовині тривалий час зберігатися та мати підвищену стійкість до факторів розкладання, таких як вплив температури, вільні радикали і ферменти (рис. 1, 2). Також стабілізація гіалуронової кислоти за допомогою БДДЕ дає змогу підвищити її в'язкість, оптимізувавши важливі для фізіологічної активності реологічні властивості [12]. 


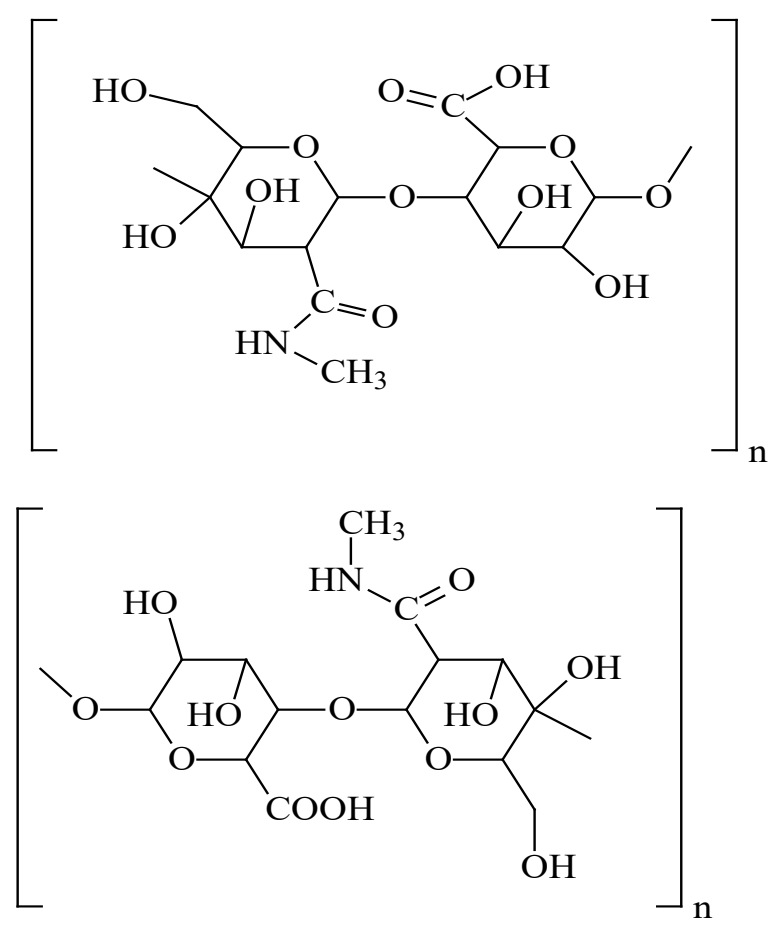

Рис. 1. Молекула гіалуронової кислоти, що одержана шляхом бактеріальної ферментації

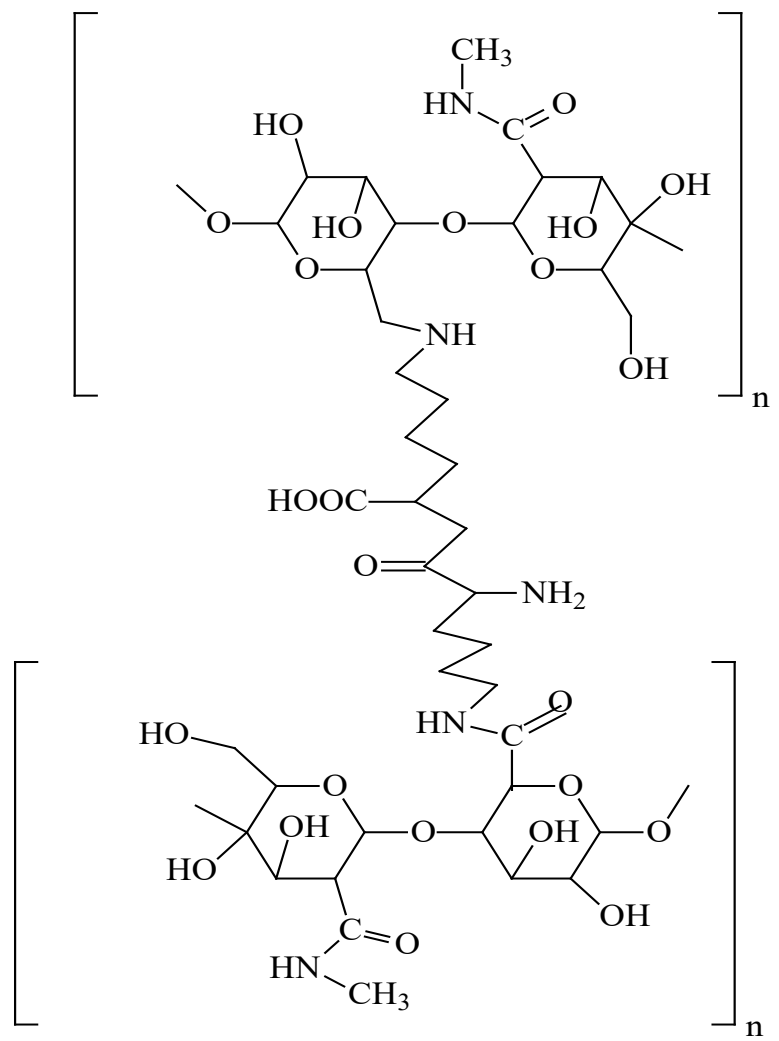

Рис. 2. Молекула поперечно-зшитого гіалуронату натрію, стабілізованого БДДЕ

Також до складу було введено допоміжні речовини, які є компонентами синовіальної рідини та забезпечують її осмоляльність і буферні властивості. Так, натрію хлорид використано в ізотонічній концентрації, натрію дигідрофосфат дигідрату і 
динатрію гідрофосфат додекагідрат - для створення буферної системи. Таким чином, розроблений склад містить у \%: натрію гіалуронат із молекулярною масою 2 МДа (в перерахунку на $100 \%$ речовину) - 1,0; БДДЕ - 0,75; натрію хлорид - 0,85; фосфатний буфер - до рН від 5,0 до 8,5; води для ін'єкцій - до 100\%. Отриманий розчин за фізико-хімічними властивості являє собою прозорий високов'язкий водний розчин.

Вибраний склад є досить непростим із точки зору розроблення технології виробництва через дуже високу в'язкість. Під час розроблення технології одержання препарату виконували дослідження таких критичних стадій виробництва: стабілізація гіалуронату натрію, вибір технологічних операцій для одержання однорідного прозорого розчину (перемішування, фільтрація), розлив розчину в контейнери, стерилізація.

3 експериментальних досліджень щодо отримання розчину гіалуронату натрію встановлено, що для цього АФІ біотехнологічного походження неможливо одержати розчин для ін'єкцій фармацевтичної якості стандартними технологічними операціями. Так, певні складнощі з одержанням продукту відбулись на стадіях перемішування (утворення газової емульсії високов'язкого водного розчину) та стерилізуючої фільтрації (молекули високов'язкого розчину не проходить крізь пори фільтра). Отже, наступними етапами досліджень було вирішення таких складних і водночас найменш охарактеризованих у літературі технологічних стадій, як розроблення технології дегазації розчину від утвореної газової емульсії (дезаерація), фільтрація та підбір режиму стерилізації ін'єкційного розчину натрію гіалуронату.

Вибір оптимальних умов стадії дегазації здійснювали між наступними варіантами згідно 3 матрицею досліджень. Газова емульсія призводить до зниження електричного потенціалу молекул АФІ, руйнує хімічні зв'язки, безпосередньо впливає на стабільність лікарського засобу та може призвести до виникнення побічної дії препарату за рахунок явища емболії. Отже, для приготованого розчину препарату було випробувано різні режими дегазації. Як критерій оцінки режиму дегазації визначено основні показники для контролю якості розчину препарату: основний критерій успішності дегазації - кількість видимих пухирців повітря у одному шприці обсягом 2 мл; опис; в’ язкість - показник якості, що залежить від молекулярної масу та відповідно демонструє чи не була пошкоджена структура молекул АФІ під час дегазації. Результати досліджень наведено в табл. 1.

Т а б ли ц я 1

\section{Критерії оцінки та результати досліджень вибору технології дегазації} розчину гіалуронату натрію

\begin{tabular}{|c|c|c|c|}
\hline 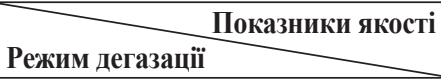 & $\begin{array}{c}\text { Опис. Прозорий однорід- } \\
\text { ний водний розчин }\end{array}$ & $\begin{array}{c}\text { Кількість пухирців у } \\
2 \text { мл розчину } \\
\end{array}$ & $\begin{array}{c}\text { Відносна в'язкість. } \\
\text { Від 1,13 до 1,38 } \\
\end{array}$ \\
\hline $\begin{array}{c}\text { Вакуумування розчину при } \\
\text { перемішуванні (300 мбар) }\end{array}$ & Не відповідає & 30 & Відповідає \\
\hline $\begin{array}{c}\text { Вакуумування розчину при } \\
\text { перемішуванні (100 мбар) }\end{array}$ & Не відповідає & 5 & Відповідає \\
\hline $\begin{array}{l}\text { Вакуумування розчину без } \\
\text { перемішування (100 мбар) }\end{array}$ & Не відповідає & 20 & Відповідає \\
\hline $\begin{array}{c}\text { Відстоювання розчину, наповненого } \\
\text { в шприці, у вертикальному } \\
\text { положенні (14 діб) }\end{array}$ & Не відповідає & 40 & Не відповідає \\
\hline $\begin{array}{c}\text { Відстоювання розчину, наповненого } \\
\text { в шприці, у вертикальному } \\
\text { положенні (28 діб) } \\
\end{array}$ & Не відповідає & 38 & Відповідає \\
\hline $\begin{array}{c}\text { Центрифугування розчину у } \\
\text { шприцях, } 1000 \text { об/хв }\end{array}$ & Відповідає & Відсутні & Відповідає \\
\hline $\begin{array}{c}\text { Центрифугування розчину у } \\
\text { шприцях, } 3000 \text { об/хв }\end{array}$ & Відповідає & Відсутні & $\begin{array}{c}\text { Видавлювання розчину } \\
\text { зі шприця }\end{array}$ \\
\hline
\end{tabular}


За результатами досліджень щодо вибору стадії дегазації, що наведені в табл. 1, встановлено, що центрифугування розчину у первинній упаковці в режимі 1000 об/хв дає змогу одержати продукт, що відповідає вимогам ДФУ щодо лікарських засобів для парентерального застосування за обраними показниками якості. Але технологічна операція дегазації розчину у первинній упаковці придатна для виготовлення лабораторних серій. Для масштабування процесу і виробництва промислової серії було обрано режим вакуумування розчину при перемішуванні (вакуум 100 мбар), оскільки при таких умовах отримано найменшу ступінь газової емульсії. Для досягнення повної дезаерації розчину необхідно провести перспективну валідацію режиму перемішування у промисловому реакторі.

Наступним етапом досліджень було розроблення стадії фільтрації приготованого розчину. Для оцінки критичних параметрів застосовано фільтри з різним рейтингом та матеріалом мембрани. Як критичні параметри технологічного процесу досліджували температуру розчину, що подається на фільтрацію, об'єм розчину, що профільтровано, та кількість зупинок для заміни фільтра. Приготовані експериментальні серії зразків фільтрували, але для оцінки фізико-хімічних показників відбирали розчини, які за визначених умов було профільтровано в повному обсязі. Відібрані профільтровані розчини оцінювали за такими критеріями: в'язкість, $\mathrm{pH}$ розчину, кількісний вміст натрію гіалуронату. Результати досліджень подано в табл. 2.

Т а б ли ц я 2

Фізико-хімічні показники якості розчину для ін'скцій натрію гіалуронату залежно від умов фільтрації

\begin{tabular}{|c|c|c|c|c|c|}
\hline \multicolumn{3}{|c|}{ Критичні технологічні параметри } & \multicolumn{3}{|c|}{ Показники якості згідно з МКЯ } \\
\hline матеріал мембрани & $\begin{array}{c}\text { рейтинг } \\
\text { фільтра, } \\
\text { мкм }\end{array}$ & $\begin{array}{c}\text { температура } \\
\text { розчину, }{ }^{\circ} \mathrm{C} \\
\pm 0,5\end{array}$ & $\begin{array}{c}\text { динамічна } \\
\text { в'язкість } \\
\text { 10-15 Па·с }\end{array}$ & $\begin{array}{c}\mathrm{pH} \\
5,0-8,5\end{array}$ & $\begin{array}{c}\text { кількісний вміст } \\
\text { натрію гіалуронату } \\
\mathbf{9 5 , 0 - 1 0 5 , 0 \%}\end{array}$ \\
\hline \multicolumn{3}{|c|}{ Приготований розчин до фільтрації } & + & + & + \\
\hline $\begin{array}{l}\text { Поліефірсульфон, Minisart High } \\
\text { Flow, Sartorius }\end{array}$ & $\begin{array}{c}0,45 \\
1,0\end{array}$ & $\begin{array}{l}50 \\
50\end{array}$ & - & $\begin{array}{l}+ \\
+\end{array}$ & $\begin{array}{l}+ \\
+ \\
+\end{array}$ \\
\hline $\begin{array}{l}\text { Ацетат целлюлози Minisart, } \\
\text { Sartorius }\end{array}$ & $\begin{array}{c}0,45 \\
1,0 \\
\end{array}$ & $\begin{array}{l}50 \\
50 \\
\end{array}$ & - & $\begin{array}{l}+ \\
+ \\
+\end{array}$ & $\begin{array}{l}+ \\
+ \\
\end{array}$ \\
\hline $\begin{array}{l}\text { Регенерована целлюлоза } \\
\text { Minisart Sartorius }\end{array}$ & $\begin{array}{c}0,45 \\
1,0 \\
\end{array}$ & $\begin{array}{l}50 \\
50\end{array}$ & - & $\begin{array}{l}+ \\
+\end{array}$ & $\begin{array}{l}- \\
+ \\
\end{array}$ \\
\hline $\begin{array}{l}\text { Змішані ефіри целлюлози } \\
\text { (MF-Millipore) }\end{array}$ & $\begin{array}{c}0,45 \\
1,0\end{array}$ & $\begin{array}{l}50 \\
50\end{array}$ & - & $\begin{array}{l}+ \\
+\end{array}$ & $\begin{array}{l}- \\
+\end{array}$ \\
\hline $\begin{array}{l}\text { Поліефірсульфон Millex GP, } \\
\text { Millipore }\end{array}$ & $\begin{array}{c}0,45 \\
1,0 \\
\end{array}$ & $\begin{array}{l}50 \\
50 \\
\end{array}$ & - & $\begin{array}{l}+ \\
+ \\
\end{array}$ & $\begin{array}{l}+ \\
+ \\
\end{array}$ \\
\hline $\begin{array}{l}\text { Полівінілдефторид PVDF } \\
\text { (Durapore) Millipore }\end{array}$ & $\begin{array}{c}0,45 \\
1,0\end{array}$ & $\begin{array}{l}50 \\
25\end{array}$ & $\begin{array}{l}+ \\
+\end{array}$ & $\begin{array}{l}+ \\
+\end{array}$ & $\begin{array}{l}+ \\
+\end{array}$ \\
\hline
\end{tabular}

П р и м і т к а: «+» - відповідає, «-» - не відповідає.

3 даних, наведених у табл. 2, встановлено, що для проведення фільтрації необхідно піднімати температуру розчину з метою зниження в'язкості. Але температурний фактор впливає на молекулярну масу та стабільність поперечно-зшитої молекули гіалуронату натрію, про що свідчить критерій відповідності за показником відносна в'язкість. Матеріал мембрани фільтра та умови фільтрації не впливають на значення $\mathrm{pH}$ розчинів. Експериментально встановлено, що оптимальними параметрами для стадії фільтрування $\epsilon$ застосування гідрофільної мембрани «Durapore», що виконана 3 полівінілдефториду (PVDF), температура розчину - $50 \pm 0,5^{\circ} \mathrm{C}$, та при зменшенні об'єму, що фільтрується за одиницю часу, необхідно застосовувати режим протитиску (back pressure).

Із метою забезпечення стерильності ін'єкційного розчину на основі натрію гіалуронату зроблено дослідження різних режимів стерилізації препарату в первинній упа- 
ковці. На основі теоретичного аналізу нормативної документації було виконано експеримент із вибору режиму стерилізації. Приготовані експериментальні серії зразків препарату стерилізували обраними методами, такими як: серія № 1 - автоклавування насиченою парою за температури $121{ }^{\circ} \mathrm{C}$ упродовж 15 хв; серія № 2 - стерилізація за температури $121{ }^{\circ} \mathrm{C}$ упродовж 8 хв; серія № 3 - стерилізація гамма-випроміненням 25 кгрей; серія № 4 - застосували стерилізуючу фільтрацію розчину препарату за температури $50{ }^{\circ} \mathrm{C}$ в асептичних умовах через мембранні фільтри 3 рейтингом пор 0,2 мкм із наступним розливом у первинні контейнери; серія № 5 - нестерильні зразки як контроль. Придатність режиму стерилізації визначали фізико-хімічними методами (за показниками - опис, прозорість, в'язкість, $\mathrm{pH}$ розчину, кількісний вміст натрію гіалуронату) і біологічним методом (визначення стерильності) відповідно до МКЯ на препарат. Результати досліджень подано в табл. 3.

Т а б ли ц я 3

Вплив режиму стерилізації на фізико-хімічні показники якості розчину натрію гіалуронату для ін'скцій

\begin{tabular}{|c|c|c|c|c|c|c|}
\hline \multirow[b]{3}{*}{$\begin{array}{l}\text { № } \\
\text { cepiï }\end{array}$} & \multicolumn{6}{|c|}{ Показники якості згідно з МКЯ } \\
\hline & опис & прозорість & $\begin{array}{l}\text { динамічна } \\
\text { в'язкість }\end{array}$ & $\mathrm{pH}$ & стерильність & $\begin{array}{l}\text { кількісний вміст } \\
\text { натрію гіалуронату }\end{array}$ \\
\hline & $\begin{array}{c}\text { прозорий } \\
\text { однорідний } \\
\text { водний розчин }\end{array}$ & $\begin{array}{l}\text { прозорий } \\
\text { ДФУ 2.2.1 }\end{array}$ & $\begin{array}{c}\text { від } 10 \text { до } 15 \\
\text { Па с } \\
\text { ДФУ 2.2.8 }\end{array}$ & $\begin{array}{c}\text { від } 5,0 \\
\text { до } 8,5 \\
2.2 .3\end{array}$ & $\begin{array}{c}\text { Стерильний } \\
\text { ДФУ 2.6.1 }\end{array}$ & $\begin{array}{c}\text { від 95,0 } \\
\text { до } 105,0 \% \\
\text { ДФУ } 2.2 .25\end{array}$ \\
\hline 1 & + & + & - & + & + & + \\
\hline 2 & + & + & + & + & + & + \\
\hline 3 & - & - & - & - & + & + \\
\hline 4 & + & + & - & + & - & - \\
\hline 5 & + & + & + & + & - & + \\
\hline
\end{tabular}

П р и м і т к а: «+»-відповідає, «-»- не відповідає.

У результаті досліджень із вибору стерилізації одержано дані, наведені в табл. 3. Експериментально встановлено технологічні складнощі з підбором фільтра з рейтингом 0,22 мкм для проведення стерилізуючої фільтрації. Приготовану лабораторну серію розчину препарату не вдалося профільтрувати в повному об'ємі за температури розчину $50{ }^{\circ} \mathrm{C}$ через високу в'язкість для такого рейтингу фільтра. За тиску близько 3 бар руйнувалася мембрана фільтра. За тиску 1,5-2 бар розчин практично не продавлювався через фільтр. Спосіб стерилізації гамма-випромінюванням призводить до руйнування лінійних молекул і $\epsilon$, таким чином, невідповідними для гнучкого еластичного біополімерного продукту, в якому молекулярна маса є ключовим параметром для оптимальної якості продукту. Визначено, що режим стерилізації насиченим паром за температури $121{ }^{\circ} \mathrm{C}$ упродовж 8 хв $є$ оптимальним та забезпечує якість розчину за показником «Стерильність».

За результатами вибору технологічних параметрів визначено технологію одержання розчину для ін'єкцій. У реактор завантажують воду для ін'єкцій кімнатної температури, вносять натрію хлорид, натрію дигідрофосфат дигідрату і динатрію гідрофосфат додекагідрат, гіалуронат натрію, перемішують до повного розчинення. Завантажують стабілізатор БДДЕ при перемішуванні та нагріві розчину до температури $40-60{ }^{\circ} \mathrm{C}$. Розчин витримують при перемішуванні та підтриманні температури протягом 2-4 год для утворення стабілізованого натрію гіалуронату. Проводять дегазацію одержаного розчину, фільтрують та розливають у скляні шприці та укупорюють. Проводять стерилізацію розчину в первинній упаковці, маркують та пакують у вторинну упаковку. Технологічну схему виробництва лікарського засобу наведено на рис. 3. 


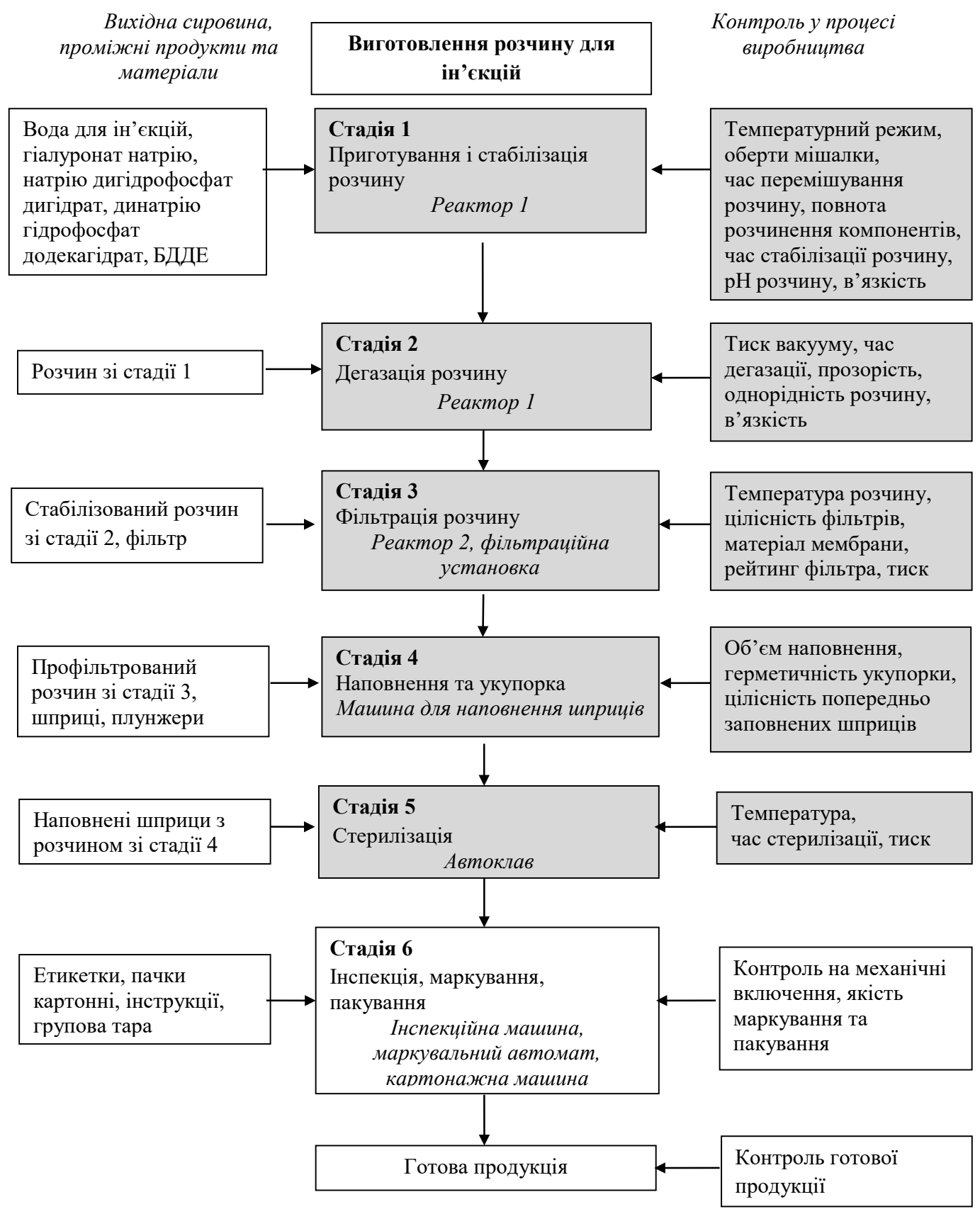

\section{Рис. 3. Технологічна схема виробництва гіалуронату натрію, розчину для ін'скцій}

Сірим кольором позначено критичні стадії та критичні точки контролю в процесі виробництва

Таким чином, розроблено оптимальний склад лікарського засобу на основі стабілізованої гіалуронової кислоти з допоміжною речовиною БДДЕ.

В и с н о в к и

1. Розроблено оптимальний склад лікарського засобу на основі стабілізованого гіалуронату натрію допоміжною речовиною БДДЕ. Одержаний розчин за фізико-хімічними властивостями являє собою прозорий високов'язкий водний розчин. Розроблений склад містить (у \%): натрію гіалуронат з молекулярною масою 2 МДа (в 
перерахунку на $100 \%$ речовину) - 1,0; БДДЕ - 0,75; натрію хлорид - 0,85; фосфатний буфер - до рН 5,0-8,5; води для ін'єкцій - до 100\%.

2. Експериментально визначено критичні параметри технологічних стадій, специфічних для виробництва лікарського засобу з гіалуронатом натрію, такі як дегазація в'язкого розчину, фільтрація та умови режиму стерилізації ін'єкційного розчину. Експериментально встановлено, що оптимальними параметрами для стадії фільтрування є застосування гідрофільної мембрани «Durapore», що виконана 3 полівінілдефториду (PVDF), температура розчину $-50 \pm 0,5{ }^{\circ} \mathrm{C}$ та застосування режиму протитиску (back pressure) для зменшення об’єму, що фільтрується за одиницю часу. Визначено, що режим стерилізації насиченим паром за температури $121{ }^{\circ} \mathrm{C}$ упродовж 8 хв є оптимальним та забезпечує якість розчину за показником «Стерильність».

3. Зразки експериментальної серії розчину для ін'єкцій, одержані за визначеною технологією, відповідають вимогам ДФУ щодо лікарських засобів для парентерального застосування за фізико-хімічними та біологічними показниками якості, такими як опис, прозорість, в’язкість, рН розчину, стерильність, кількісний вміст натрію гіалуронату.

\section{С пи сок в и користан ої літе ратури}

1. Олійник М. В., Стаднюк Л. А. Сучасна патогенетична терапія остеоартрозу, що грунтується на доказах // Мистецтво лікування. - 2010. - № 1 (67). - С. 27-30.

2. Носівец̧ь Д. С. Фармакологія хондропротекторів (огляд фармацевтичного ринку України) // Вісн. проблем біології і медицини. - 2013. - Т. 1 (104), Вип. 4. - С. 57-63.

3. Ruberg Eva-Maria. Development of sustained release formulations for the intra-articular delivery of a therapeutic antibody / Dissertation zur Erlangung des Doktorgrades der Fakultät für Chemie und Pharmazie der Ludwig-Maximilians-Universität München, 2013. - 175 p.

4. Лич I. В., Угрин А. О., Волошина I. М. Гіалуронова кислота: біосинтез та використання // Укр. біофармац. журн. - 2019. - № 2 (59). - C. 6-13. https://doi.org/10.24959/ubphj.19.212

5. Савоськин О. В., Семенова Е. Ф., Рашевская Е. Ю. и др. Характеристика различных методов получения гиалуроновой кислоты // Научное обозрение. Биол. науки. - 2017. - № 2. - С. 125-135.

6. Diraçoğlu D., Alptekin K., Teksöz B. et al. Knee vs hip single-joint intra-articular hyaluronic acid injection in patients with both hip and knee osteoarthritis: a pilot study // Clin. Rheumatol. - 2009. - V. 28, N 9. - P. 1021-1024. https://doi.org/10.1007/s10067-009-1199-7

7. Нестерчук М. М., Баула О. П., Гамазін Ю. О. та ін. Особливості біологічних/біотехнологічних продуктів та біосимілярів. Метод. рекомендації. (Схвалено на засіданні Науково-експертної ради Державного експертного центру МОЗ (протокол № 03 від 29. 03. 2013 р.). - 37 с.

8. Pramadona and Akbar Adhiutama. The Application of Lean Manufacturing for Operation Improvement: A Case Study of Black Cough Medicine Production in Indonesia // The Asian J. Technol. Management. - 2013. - V. 6, N 1. - P. 56-64. https://dx.doi.org /10.12695/ajtm.2013.6.1.5

9. Державна фармакопея України: в 3т. / ДП «Український науковий фармакопейний центр якості лікарських засобів». 2-е вид. - Харків: ДП «Український науковий фармакопейний центр якості лікарських засобів», 2015. - Т. 1. - 1128 с.

10. Sodium Hyaluronate. European Pharmacopoeia $9^{\text {th }}$, vol. 2 / European Directorate for Qulity of Medicines \& Health Care. 9.0th ed. - Strasbourg, 2016. - P. 3583-3585.

11. Зайченко Г. В., Горчакова Н. О., Стрига О. А. та ін. Аспекти фармакодинаміки та клінічної фармакології гіалуронової кислоти // Вісн. проблем біології і медицини. - 2017. - Вип. 1 (135). - С. $33-42$.

12. Pat. WO 2006021644. Water-soluble crosslinked hyaluronic acid, a metod for the preparation thereof, implant containing said crosslinked hyaluronic acid and the use thereof / Asius Jerome, Asius Benedicte, Riviere Nicolas, Giani Olivia, Robin Jean-Jacques, Vayaboury Koumalen. - Заявл. 23. 07. 2004; Опубл. 02. 03. 2006.

\section{$\mathrm{R}$ e f e r e n c e s}

1. Oliinyk M. V., Stadniuk L. A. Suchasna patohenetychna terapiia osteoartrozu, shcho gruntuietsia na dokazakh // Mystetstvo likuvannia. - 2010. - № 1 (67). - S. 27-30.

2. Nosivets D. S. Farmakolohiia khondroprotektoriv (ohliad farmatsevtychnoho rynku Ukrainy) // Visn. problem biolohii i medytsyny. - 2013. - T. 1 (104), Vyp. 4. - S. 57-63.

3. Ruberg Eva-Maria. Development of sustained release formulations for the intra-articular delivery of a therapeutic antibody / Dissertation zur Erlangung des Doktorgrades der Fakultät für Chemie und Pharmazie der Ludwig-Maximilians-Universität München, 2013. - 175 r.

4. Lych I. V., Uhryn A. O., Voloshyna I. M. Hialuronova kyslota: biosyntez ta vykorystannia // Ukr. biofarmats. zh. - 2019. - № 2 (59). - S. 6-13. https://doi.org/10.24959/ubphj.19.212 
5. Savoskyn O. V., Semenova E. F., Rashevskaia E. Yu. y dr. Kharakterystyka razlychnikh metodov poluchenyia hyaluronovoi kysloti // Nauchnoe obozrenye. Byol. nauky. - 2017. - № 2. - S. 125-135.

6. Diraçoğlu D., Alptekin K., Teksöz B. et al. Knee vs hip single-joint intra-articular hyaluronic acid injection in patients with both hip and knee osteoarthritis: a pilot study // Clin. Rheumatol. - 2009. - V. 28, N 9. - P. 1021-1024. https://doi.org/10.1007/s10067-009-1199-7

7. Nesterchuk M. M., Baula O. P., Hamazin Yu. O. ta in. Osoblyvosti biolohichnykh/biotekhnolohichnykh produktiv ta biosymiliariv. Metod. pekomendatsii. (Skhvaleno na zasidanni Naukovo-ekspertnoi rady Derzhavnoho ekspertnoho tsentru MOZ (protokol № 03 vid 29. 03. 2013 r.). - 37 s.

8. Pramadona and Akbar Adhiutama. The Application of Lean Manufacturing for Operation Improvement: A Case Study of Black Cough Medicine Production in Indonesia // The Asian J. Technol. Management. - 2013. - V. 6, N 1. - R. 56-64. https://dx.doi.org /10.12695/ajtm.2013.6.1.5

9. Derzhavna farmakopeia Ukrainy: v 3t. / DP «Ukrainskyi naukovyi farmakopeinyi tsentr yakosti likarskykh zasobiv». 2-e vyd. - Kharkiv: DP «Ukrainskyi naukovyi farmakopeinyi tsentr yakosti likarskykh zasobiv», 2015. - T. 1. - $1128 \mathrm{~s}$.

10. Sodium Hyaluronate. European Pharmacopoeia 9th, vol. 2 / European Directorate for Qulity of Medicines \& Health Care. 9.0th ed. - Strasbourg, 2016. - P. 3583-3585.

11. Zaichenko H. V., Horchakova N. O., Stryha O. A. ta in. Aspekty farmakodynamiky ta klinichnoi farmakolohii hialuronovoi kysloty // Visn. problem biolohii i medytsyny. - 2017. - Vyp. 1 (135). - S. 33-42.

12. Pat. WO 2006021644. Water-soluble crosslinked hyaluronic acid, a metod for the preparation thereof, implant containing said crosslinked hyaluronic acid and the use thereof / Asius Jerome, Asius Benedicte, Riviere Nicolas, Giani Olivia, Robin Jean-Jacques, Vayaboury Koumalen. - Zaiavl. 23. 07. 2004; Opubl. 02. 03. 2006.

Надійшла до редакції 29 липня 2019 р. Прийнято до друку 8 вересня 2019 р.

О. О. Салій ${ }^{1}$ (https://orcid.org/0000-0001-7103-2083),

О. В. Лось ${ }^{2}$ (https://orcid.org/0000-0002-7830-6937),

О. П. Баула ${ }^{1}$ (https://orcid.org/0000-0003-4305-6517),

К. Ф. Мацюця ${ }^{1}$ (https://orcid.org/0000-0001-6704-6511)

${ }^{1}$ Київський національний університет технологій та дизайну

${ }^{2}$ Фармацевтична корпорачія «Юрія-Фарм», м. Київ

РОЗРОБЛЕННЯ СКЛАДУ ТА ТЕХНОЛОГІЇ ВИРОБНИЦТВА ІН'ЄКЦИЙНОГО ЛІКАРСЬКОГО

ЗАСОБУ ДЛЯ ВНУТРІШНЬОСУГЛОБОВОГО ВВЕДЕННЯ НА ОСНОВІ ГІАЛУРОНАТУ НАТРІЮ

Ключові слова: гіалуронат натрію, розчин для ін'єкцій, розроблення складу, технологія виробництва, стабілізація розчину

А Н О Т А ЦІ Я

Остеоартроз є найпоширенішим захворюванням опорно-рухового апарату людини, який у 10-30\% випадків призводить до непрацездатності різного ступеня, причому вік пацієнта є одним із найважливіших факторів ризику його розвитку. Хірургічні операції зі заміни суглоба $є$ найефективнішим рішенням, але такий метод дуже ризикований та дорогий, особливо для людей похилого віку. Таким чином, розроблення складу та пошук новітніх технологічних аспектів лікарських засобів біотехнологічного походження є актуальним напрямом сьогодення фармації.

Мета роботи - розроблення складу та технології виготовлення ін'єкційного розчину кислоти гіалуронової у формі натрію гіалуронату для терапії дегенеративних запальних захворювань суглобів.

Об’єктом дослідження є розчин для ін'єкцій із гіалуронатом натрію для внутрішньосуглобового введення.

Оцінку результатів випробувань під час вибору оптимальної технології приготування розчину для ін'єкцій здійснювали візуальним методом (опис, прозорість) та методом ротаційної віскозиметрії (в'язкість). Придатність режиму стерилізації визначали фізико-хімічними методами (опис, прозорість, в'язкість, $\mathrm{pH}$ розчину) і мікробіологічним методом (стерильність) згідно з вимогами ДФУ. Кількісний вміст натрію гіалуронату визначали методом спектрофотометрії (ДФУ, 2.2.25) із використанням реагенту карбазолу.

У результаті досліджень розроблено оптимальний склад лікарського засобу на основі стабілізованого гіалуронату натрію допоміжною речовиною БДДЕ. Отриманий розчин за фізико-хімічними властивості являє собою прозорий високов'язкий водний розчин. Розроблений склад містить (у \%): натрію гіалуронат з молекулярною масою 2 МДа (в перерахунку на 100\% речовину) - 1,0; БДДЕ - 0,75; натрію хлорид - 0,85; фосфатний буфер - до рН 5,0-8,5; води для ін'єкцій - до $100 \%$.

Експериментально визначено критичні параметри технологічних стадій, специфічні для виробництва лікарського засобу з гіалуронатом натрію, такі як дегазація в'язкого розчину, фільтрація та умови режиму стерилізації ін'єкційного розчину. Експериментально встановлено, що оптимальними параметрами для стадії фільтрування є застосування гідрофільної мембрани «Durapore», що виконана 3 полівінілдефториду (PVDF), температура розчину $-50 \pm 0,5^{\circ} \mathrm{C}$ та застосування режиму протитиску (back 
pressure) для зменшення об'єму, що фільтрується за одиницю часу. Визначено, що режим стерилізації насиченим паром за температури $121^{\circ} \mathrm{C}$ упродовж 8 хв $є$ оптимальним та забезпечує якість розчину за показником «Стерильність».

Зразки експериментальної серії розчину для ін'єкцій, одержані за визначеною технологією, відповідають вимогам ДФУ щодо лікарських засобів для парентерального застосування за фізико-хімічними та біологічними показниками якості, такими як опис, прозорість, в'язкість, рН розчину, стерильність, кількісний вміст натрію гіалуронату.

Е. А. Салий ${ }^{1}$ (https://orcid.org/0000-0001-7103-2083),

A. В. Лось ${ }^{2}$ (https://orcid.org/0000-0002-7830-6937),

О. П. Баула ${ }^{1}$ (https://orcid.org/0000-0003-4305-6517),

Е. Ф. Мацюця ${ }^{1}$ (https://orcid.org/0000-0001-6704-6511)

${ }^{1}$ Киевский национальный университет технологий и дизайна

${ }^{2}$ Фармаиевтическая корпораиия «Юрия-Фарм», г. Киев

РАЗРАБОТКА СОСТАВА И ТЕХНОЛОГИИ ПРОИЗВОДСТВА ИНЪЕКЦИОННОГО

ЛЕКАРСТВЕННОГО СРЕДСТВА ДЛЯ ВНУТРИСУСТАВНОГО ВВЕДЕНИЯ НА ОСНОВЕ

ГИАЛУРОНАТА НАТРИЯ

Ключевые слова: гиалуронат натрия, раствор для инъекций, разработка состава, технология производства, стабилизация раствора

А Н Н О Т А ЦИ Я

Остеоартроз является наиболее распространенным заболеванием опорно-двигательного аппарата человека, который в 10-30\% случаев приводит к неработоспособности различной степени, причем возраст пациента является одним из важнейших факторов риска его развития. Хирургические операции по замене сустава являются наиболее эффективным решением, но такой метод очень рискованный и дорогой, особенно для пожилых людей. Таким образом, разработка состава и поиск новейших технологических аспектов лекарственных средств биотехнологического происхождения является актуальным направлением настоящего фармации.

Цель работы - разработка состава и технологии изготовления инъекционного раствора гиалуроновой кислоты в форме гиалуроната натрия для терапии дегенеративных воспалительных заболеваний суставов.

Объектом исследования является раствор для инъекций с гиалуронатом натрия для внутрисуставного введения.

Оценку результатов испытаний при выборе оптимальной технологии приготовления раствора для инъекций проводили визуальным методом (описание, прозрачность), и методом ротационной вискозиметрии (вязкость). Пригодность режима стерилизации определяли физико-химическими методами (описание, прозрачность, вязкость, $\mathrm{pH}$ раствора) и микробиологическим методом (стерильность) согласно требованиям ГФУ. Количественное содержание натрия гиалуроната определяли методом спектрофотометрии (ГФУ, 2.2.25) с использованием реагента карбазола.

В результате исследований разработан оптимальный состав лекарственного средства на основе стабилизированного гиалуроната натрия вспомогательным веществом БДДЕ. Полученный раствор по физико-химическим свойствам представляет собой прозрачный высоковязкий водный раствор. Разработанный состав содержит (в \%): натрия гиалуронат с молекулярной массой 2 МДА (в пересчете на $100 \%$ вещество) - 1,0; БДДЕ - 0,75; натрия хлорид - 0,85; фосфатный буфер - до рН 5,0-8,5; воды для инъекций - до $100 \%$.

Экспериментально определены критические параметры технологических стадий, специфические для производства лекарственного средства с гиалуронатом натрия, такие как дегазация вязкого раствора, фильтрация и условия режима стерилизации инъекционного раствора. Экспериментально установлено, что оптимальными параметрами для стадии фильтрации является применение гидрофильной мембраны «Durapore», выполненной из поливинилдефторида (PVDF), температура раствора - $50 \pm$ $0,5^{\circ} \mathrm{C}$ и применение режима противодавления (back pressure) для уменьшения объема, который фильтруется за единицу времени. Определено, что режим стерилизации насыщенным паром при температуре $121^{\circ} \mathrm{C}$ в течение 8 мин является оптимальным и обеспечивает качество раствора по показателю «Стерильность».

Образцы экспериментальной серии раствора для инъекций, полученные по разработанной технологии, соответствуют требованиям ГФУ для лекарственных средств для парентерального применения по физико-химическим и биологическим показателям качества, таким как описание, прозрачность, вязкость, $\mathrm{pH}$ раствора, стерильность, количественное содержание натрия гиалуроната. 
O. O. Saliy ${ }^{1}$ (https://orcid.org/0000-0001-7103-2083),

O. V. Los ${ }^{2}$ (https://orcid.org/0000-0002-7830-6937),

O. P. Baula ${ }^{1}$ (https://orcid.org/0000-0003-4305-6517),

K. F. Matsiutsia ${ }^{1}$ (https://orcid.org/0000-0001-6704-6511)

${ }^{1}$ Kyiv National University of Technologies and Design

${ }^{2}$ Pharmaceutical Corporation «Yuria-Pharm», Kyiv

DEVELOPMENT OF THE COMPOSITION AND PRODUCTION TECHNOLOGY OF INJECTION

MEDICATION FOR INTRA-ARTICULAR INTRODUCTION BASED ON SODIUN HYALURONATE

Key words: sodium hyaluronate; solution for injection; composition development; production technology;

stabilization of the solution

A B S T R A C T

Osteoarthrosis is the most widespread disease of musculoskeletal system, which leads to different level of disability in $10-30 \%$ of cases. The age of the person is one of the key risk factors for the development of such disease. The most effective resolution is a surgery in which joints are replaced, but this method is very risky and expensive especially for elderly people. That is why development of the composition and research in new technological aspects of biotechnological medication is an actual course in pharmacy.

The aim of research: development of the composition and production technology of injection solution of hyaluronic acid as sodium hyaluronate for the therapy of degenerate inflammatory disease of articulation.

The object of the study is an injection with sodium hyaluronate for intra-articular administration.

Evaluation of the test results when choosing the optimal technology for preparing the injection solution was carried out by the visual method (description, transparency), and by the method of rotational viscometry (viscosity). The suitability of the sterilization regime was determined by physicochemical methods (appearance, transparency, viscosity, $\mathrm{pH}$ of the solution) and microbiological method (sterility) according to the requirements of SPhU. The quantitative content of sodium hyaluronate was determined by spectrophotometry $(\mathrm{SPhU}, 2.2 .25)$ using a carbazole reagent.

The results of the studies has been developed the optimal composition of the drug based on stabilized sodium hyaluronate by the excipient BDE. The resulting solution in its physical-chemical properties are a clear, highly viscous aqueous solution. The developed composition contains (in \%): Sodium hyaluronate with a molecular weight of $\sim 2$ MDA (in terms of $100 \%$ substance) - 1.0; BDE - 0.75; sodium chloride - 0.85; phosphate buffer - up to $\mathrm{pH}$ from 5.0 to 8.5 ; water for injection - up to $100 \%$.

The critical parameters of the technological stages for the production of a drug with sodium hyaluronate are determined experimentally. Specific critical parameters are the degassing of a viscous solution, filtration and the conditions of the sterilization mode of the injection solution. It was experimentally established that the optimal parameters for the filtration stage are the use of a Durapore hydrophilic membrane made of polyvinyl difluoride (PVDF), the temperature of the solution is $50 \pm 0.5^{\circ} \mathrm{C}$ and the use of back pressure mode to reduce the volume wich is filtered per unit time. It was determined that the sterilization mode with saturated steam at a temperature of $121^{\circ} \mathrm{C}$ for $8 \mathrm{~min}$ is optimal and ensures the quality of the solution in quality criterion of «Sterility».

Samples of the experimental series of injection solution, obtained by the developed technology, comply with the requirements of SPhU for drugs for parenteral use according to physical-chemical and biological quality criteria as appearance, transparency, viscosity, $\mathrm{pH}$ of the solution, sterility, assay sodium hyaluronate.

\section{Електронна адреса для листування завторами: saliy.oo@knutd.edu.ua}

(Салій О. О.) 